\title{
Estimating market access in non-GPA countries: A suggested methodology
}

\section{Anirudh Shingal}

\begin{abstract}
The WTO's Agreement on Government Procurement (GPA) has data reporting obligations for all its Contracting Parties. Submitting such data promotes transparency in public procurement and also signals tendencies towards discrimination. However, most developing countries, especially emerging economies, are nonmembers of the GPA and therefore have no comparable data reporting obligations. In most cases, this has led to an absence of any reliable data on these countries' public purchases, which poses a serious challenge in international negotiations on the subject and in examining the impact of protectionist measures in these countries' public markets. In this short paper, we attempt to overcome these data challenges by developing a methodology to estimate the size of procurement markets in non-GPA countries as well as foreign market access therein. We also show the results from this methodology for estimating the EU's access in select emerging economies' public markets.
\end{abstract}

Key words: Government procurement, non-GPA countries, data reporting, market access, emerging economies

JEL classification: F10, F13, F17, H57

NCCR TRADE WORKING PAPERS are preliminary documents posted on the NCCR Trade Regulation website (<www.nccr-trade.org $>$ ) and widely circulated to stimulate discussion and critical comment. These papers have not been formally edited. Citations should refer to a "NCCR Trade Working Paper", with appropriate reference made to the author(s).

Research for this paper was funded by the Swiss National Science Foundation under a grant to the National Centre of Competence in Research on Trade Regulation, based at the World Trade Institute of the University of Bern, Switzerland.

\section{FNSWF}

FONDS NATIONAL SUISSE SCHWEIZERISCHER NATIONALFONDS SWISS NATIONAL SCIENCE FOUNDATION
Die Nationalen Forschungsschwerpunkte (NFS) sind ein Förderinstrument des Schweizerischen Nationalfonds. Les Pôles de recherche nationaux (PRN) sont un instrument d'encouragement du Fonds national suisse.

The National Centres of Competence in Research (NCCR) are a research instrument of the Swiss National Science Fondation. 


\title{
Estimating market access in non-GPA countries: A suggested methodology
}

\author{
Anirudh Shingal ${ }^{1}$
}

\section{March 2012}

\begin{abstract}
The WTO's Agreement on Government Procurement (GPA) has data reporting obligations for all its Contracting Parties. Submitting such data promotes transparency in public procurement and also signals tendencies towards discrimination. However, most developing countries, especially emerging economies, are non-members of the GPA and therefore have no comparable data reporting obligations. In most cases, this has led to an absence of any reliable data on these countries' public purchases, which poses a serious challenge in international negotiations on the subject and in examining the impact of protectionist measures in these countries' public markets. In this short paper, we attempt to overcome these data challenges by developing a methodology to estimate the size of procurement markets in non-GPA countries as well as foreign market access therein. We also show the results from this methodology for estimating the EU's access in select emerging economies' public markets.
\end{abstract}

Key words: Government procurement, non-GPA countries, data reporting, market access, emerging economies

JEL classification: F10, F13, F17, H57

\footnotetext{
${ }^{1}$ Senior Research Fellow, WTI \& Research Affiliate, CARIS. I would like to thank the Swiss National Science Foundation (NCCR Trade Regulation) for financial support. The usual disclaimer applies.

Address for correspondence: World Trade Institute, Hallerstrasse 6, CH - 3012, Bern, Switzerland.

Email: anirudh.shingal@wti.org.
} 


\section{Introduction}

The WTO's Agreement on Government Procurement (GPA) is a plurilateral agreement that aims to ensure transparency and non-discrimination in public purchases. The GPA was first negotiated during the Tokyo Round of Multilateral Trade Negotiations (1973-79) and came into effect on January 1, 1981. A 1987 Protocol amended the Tokyo Round Procurement Code and the new version entered into force on January 1, 1988. The GPA, as it stands today, was negotiated in parallel with the Uruguay Round of the GATT and came into effect on January 1, 1996. The URGPA now has 42 Contracting Parties as its signatories ${ }^{2}$, who have recently ${ }^{3}$ negotiated a new deal updating the procurement rules set in the URGPA and offering additional market access opportunities.

Article XIX: 5 of the URGPA requires that all Contracting Parties report data on procurement by government entities to the Committee on Government Procurement. These data pertain to the value and the number of contracts awarded by government procuring entities to winning suppliers who bid for them through oneof the three procurement practices outlined in the Agreement - open tendering, selective tendering and limited tendering. The GPA requires that only procurement above a certain threshold value be subject to internationally competitive bidding.

The data requirements under Article XIX: 5 of the URGPA are comprehensive ${ }^{4}$ and in so far as GPA signatories submit these data ${ }^{5}$, the latter are the most reliable source of information on both the size of public markets in these countries and the extent to which these markets are contestable. In fact, submitting data on procurement is one of the best ways of ensuring transparency in public procurement and highlighting any break in trend in public purchase decisions that signals discrimination. However, most developing countries, especially emerging economies, are non-members of the GPA and therefore have no comparable data reporting obligations. In most cases, this has led to an absence of any reliable data on these countries' public purchases, which poses a serious challenge in international negotiations on the subject of procurement liberalization as well as in examining the impact of protectionist measures in these countries' public markets on access to foreign firms. Both of these are significant objectives which can be successfully addressed only with reliable and adequate data.

Moreover it turns out that the data reporting requirements under Article XVI: 4 of the text of the recently revised GPA deal are less onerous. For instance, in a significant departure from Article XIX: 5(b) of the URGPA, the number and value of central government contracts are no longer required to be reported by the nationality of the winning supplier.This would make it impossible to get information on actual foreign market access in the central government procurement markets of even the GPA signatories.

In this short paper, we attempt to overcome these data challenges by developing a methodology to estimate the size of procurement markets in non-GPA countries as well as foreign market

\footnotetext{
${ }^{2}$ This list includes Armenia, Canada, the European Community and its 27 constituents, Hong Kong, Iceland, Israel, Japan, Liechtenstein, the Netherlands with respect to Aruba, Norway, Singapore, South Korea, Switzerland, Taiwan and the United States. In addition, Albania, China, Georgia, Jordan, the Kyrgyz Republic, Moldova, Oman, Panama and Ukraine are in the process of negotiating their accession to the GPA. The list comprises primarilydeveloped countries with Australia and New Zealand being notable exceptions; most developing and all LDCs have chosen not to be a part of the GPA.

${ }^{3}$ The negotiations on government procurement were concluded successfully on 15 December 2011.

${ }^{4}$ Article XIX:5(a) of the URGPA requires data to be submitted on the value of contracts awarded both above and below the threshold. Article XIX:5(b) requires data on above-thresholdprocurement to be classified by procuring entities and by goods and services according to the nationality of the winning supplier. Article XIX:5(c) requires data on the use of limited tendering practices broken down by entity and by categories of goods and services and Article XIX:5(d)on derogations from the principles of Most Favoured Nation and National Treatment.

${ }^{5}$ Unfortunately, only half of the 42 Contracting Parties (Canada, EU-15, Hong Kong, Japan, Norway and the United States) have made statistical submissions regularly since the URGPA came into being and even amongst these, there are significant differences, both in terms of what is included and how it is included.
} 
access therein. We also show the results from this methodology for estimating the EU's access in select emerging economies' public markets - these comprise the BRIC \& Turkey. In addition to the methodological contribution, these results may also be useful in the context of the on-going EU-India bilateral negotiations towards a preferential trade agreement (PTA).

\section{Estimating the size of contestable government procurement market in non- GPA countries}

In the absence of actual data on government procurement, information on the size of public markets in non-GPA countries is gleaned from government expenditure data for them, available from their national budget documents. Such data are also compiled by the IMF's Government Finance Statistics, the OECD and the UN's Standard National Accounts (SNA).

Data availability constraints meant that we needed to use data on government expenses from different sources,such as the OECD (for Russia \& Turkey), UN SNA (for Brazil \& India) and China Statistics Census. Unfortunately, data were not available for Brazil in 2007 and only until 2004 for China.

Total government expenditure includes government's consumption expenses and investment or gross capital formation expenditure. This amount needs to be adjusted to exclude estimates of defence expenditure, compensation of employees, expenses on items like interest payments, subsidies, debt write-offs, welfare payments, grants and loans and payments to international organizations like the IMF, to provide an estimate of contestable public procurement.

Thus, we have:

\section{Adjusted GG expenses $=$ GFCE + GFKF $-($ COE + Subsd + NCT + NKT $)$}

where

$\mathrm{GG}=$ General government $^{6}$

GFCE $=$ Government Final Consumption Expenditure

GFKF $=$ Government Fixed Capital Formation

$\mathrm{COE}=$ Compensation of employees

Subsd $=$ Subsidies

NCT $=$ Net Current Transfers

NKT $=$ Net Capital Transfers

However, these adjusted expenses arenot directly translatable into an estimate of the contestable procurement market. To begin with, the entire amount would not be subject to the rules of an international agreement such as the WTO's GPA. Then not all procurement contracts are above GPA-specified thresholds. Finally, most large value contracts are in services but most services remain uncovered in the GPA andeven for scheduled services, market access restrictions often remain high so that procurement markets may remain effectively uncontested.

In view of the above, we provide two sets of estimates, which can be taken as the minimum lower and the maximum upper bound of the likely contestable procurement markets in our nonGPA countries. Our first set of estimates, reported in Table 1 below, assume that $10 \%$ of the adjusted government expenses are contestable in the case of BRIC \& Turkey. Our second set of estimates, also reported in the table below, assume that $30 \%$ of the adjusted government expenses are contestable, which therefore simply triples the size of the market in these countries. With these estimates, the size of the contestable markets in these countries ranges from €9.3 -

\footnotetext{
${ }^{6}$ According to the OECD, general government accounts are consolidated central, state and local government accounts, social security funds and non-market non-profit institutions controlled and mainly financed by government units.
} 


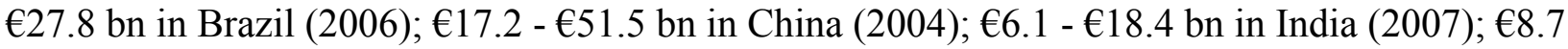
- $€ 26$ bn in Russia (2007); and €3.8 - €11.3 bn in Turkey (2007).

As it turns out, there are several justifications for the analysis here and the assumptions made.

Firstly, the $10-30 \%$ share of adjusted expenses that we consider contestable is in line with the share of contestable (above-threshold) in total procurement calculated from the actual data submissions by EU (14\%), Korea (32.6\%) and Japan (33.8\%) to the $\mathrm{WTO}^{7}$. In fact, in keeping with the rising shares of contestable procurement in the total since the year 2000 , our $10 \%$ lower bound is higher than the 5\% shares calculated for developed countries during the 1980s (Hoekman, 1997) and the 1990s (OECD, 2002; Evenett\&Shingal, 2006; Shingal, 2005, 2011).

Secondly, since the definition of General Government according to the Statistical Glossary of the OECD includes all levels of government, the 30\% share is a strict upper bound as non-GPA countries are unlikely to subject non-Annex 1 procurement to the same extent of liberalization as Annex 1 procurement ${ }^{8}$. Even so, our estimates are smaller than the magnitudes of contestable procurement markets for these countries that Anderson et.al.(2011a, p. 14-15) calculate; the latter correspond to a share of contestable in total procurement ranging from $17-33 \%$. In fact, a 10 $20 \%$ share of contestable procurement in the total may be a more realistic magnitude of de jure market access in non-GPA countries.

Table 1: Estimates of contestable public procurement markets in non-GPA countries

\begin{tabular}{|c|c|c|c|c|c|c|c|}
\hline \multirow{2}{*}{ Country } & \multirow[b]{2}{*}{ Year } & \multicolumn{2}{|c|}{ Adjusted GG Expenses } & \multicolumn{2}{|c|}{ Contestable market (€ bn) } & \multicolumn{2}{|c|}{ Contestable market (share of GDP, \% } \\
\hline & & $€$ bn & Share of GDP (\%) & Lower boun & Upper bound & Lower bound & Upper bound \\
\hline Brazil & 2006 & 92.7 & 10.4 & 9.3 & 27.8 & 1.0 & 3.1 \\
\hline Russia & 2006 & 83.0 & 10.8 & 8.3 & 24.9 & 1.1 & 3.2 \\
\hline Russia & 2007 & 86.5 & 8.8 & 8.7 & 26.0 & 0.9 & 2.7 \\
\hline India & 2006 & 50.8 & 6.7 & 5.1 & 15.2 & 0.7 & 2.0 \\
\hline Turkey & 2006 & 34.6 & 8.2 & 3.5 & 10.4 & 0.8 & 2.4 \\
\hline Turkey & 2007 & 37.8 & 8.1 & 3.8 & 11.3 & 0.8 & 2.4 \\
\hline China & 2006 & n.a. & n.a. & n.a. & n.a. & n.a. & n.a. \\
\hline China & 2007 & n.a. & n.a. & n.a. & n.a. & n.a. & n.a. \\
\hline China & 2004 & 171.7 & 14.1 & 17.2 & 51.5 & 1.4 & 4.2 \\
\hline
\end{tabular}

Source: OCED for Russia \& Turkey; UN SNA for Brazil \& India; China Statistics Census for China.

Note: GG stands for General Government; n.a. data not available. In the case of Brazil \& India, adjusted GG expenses $=$ GFCE + GFKF - COE as data was unavailable for the other attributes. For China, adjusted GG expenses $=$ Total Govt. Expd. $-($ National Defense + Administrative Expenses + Pension \& Social Welfare Expd. + Subsidies $)$ as we needed to use a different data source. Lower bound is estimated at $10 \%$ of adjusted GG expenses. Upper bound is estimated at $30 \%$ of adjusted GG expenses.

\section{Estimating foreign market access in non-GPA countries' public markets}

Estimates of contestable procurement markets in non-GPA countries can be computed using the methodology in the preceding section. To arrive at estimates of foreign procurement and a particular partner's (in our illustrative case, the EU's) market access disaggregated by sectors, we use the methodology described below, in the spirit of the following statement: "the likely eventual success rate of each country's suppliers in selling into GPA-covered public procurement markets should be evaluated in light of available information concerning their respective competitiveness in international markets generally." (Anderson et.al., 2011a, p 22)

\footnotetext{
${ }^{7}$ On the other hand, the US reports a 99\% share for contestable procurement in the total in the year 2007 and given the less-liberalized nature of non-GPA countries on the whole and political economy constraints in liberalizing procurement markets therein, it is unlikely that any of them would subject more than $30 \%$ of their public purchases to internationally competitive bidding. Norway $(93 \%, 2007)$, Lichtenstein $(100 \%, 2010)$ and Hong Kong (98\%, 2010) too report very high shares of contestable procurement in the totalbut these are all much smaller economies and also more liberal than our set of emerging economies.

${ }^{8}$ India is a case in point that has often expressed a willingness to liberalize only Annex 1 procurement, if at all.
} 
The estimate ofa non-GPA country'scontestable procurement marketis first multiplied by the share of itspublic imports in its total government demand. The data on the latter are taken from the GTAPdatabase for the year 2007. This yields an estimate of this country's foreign procurement, which is then multiplied by the share of a particular partner's exports in the nonGPA country'stotal imports. Data on the latter are taken from UN Comtrade for bilateral goods trade and the OECD for bilateral services trade. This productprovides an estimate of thatpartner's access in the non-GPA country'sprocurement market. This last estimate is then disaggregated by sector according to the relative share of each sector in the non-GPA country'stotal government demand (taken from GTAP data again).

Thus, we have:

$$
M A_{i j k t}=\left[A T_{j t} *\left(G^{M d}{ }_{j k t} / G^{T d}{ }_{j k t}\right) *\left(X_{i k t} / M_{j k t}\right)\right]^{*}\left(G^{T d}{ }_{j k t} / \sum G^{T d}{ }_{j k t}\right)
$$

where

$\mathrm{MA}_{\mathrm{ijkt}}=$ Estimate of country i's access in partner j's procurement market in sector $\mathrm{k}$ at time $\mathrm{t}$

$A T_{j}=$ Estimate of contestable public procurement in partner $\mathrm{j}$

$\mathrm{G}^{\mathrm{Md}}{ }_{\mathrm{jk}} / \mathrm{G}^{\mathrm{Td}}{ }_{\mathrm{jk}}=$ Share of imported government demand in total government demand in partner $\mathrm{j}$

$\mathrm{X}_{\mathrm{ik}} / \mathrm{M}_{\mathrm{jk}}=$ Share of country i's private sector exports in partner j's private sector imports

$\mathrm{G}^{\mathrm{Td}}{ }_{\mathrm{jkt}} / \sum \mathrm{G}^{\mathrm{Td}}{ }_{\mathrm{jkt}}=$ Relative share of sector $\mathrm{k}$ in total government demand in partner $\mathrm{j}$

This methodology is not without its shortcomings.

Firstly, these estimates of public market access assume that the share of apartner's exports in a non-GPA country's total imports is identical for the public sector and the private sector. These estimates also assume that the composition of a non-GPA country's public importsis identical to the composition of its aggregate government demand. Both of these are restrictive but necessary assumptions.

Secondly, imported government demand in GTAP data does not capture the participation of foreign affiliates in public markets and to the extent that this participation is positive, our methodologyunderestimatesthe value of foreign procurement. On the other hand, GTAP data seem to grossly overstate the value of public imports. For instance, the ratio of public imports in GTAP to those reported to the WTO (actual data) for the year 2007 is 5.8 for Japan and 4 for the EU. Fortunately for us though, this discrepancy is unlikely to influence our results significantly as we use the share of imported government demand in total government demand $\left(\mathrm{G}^{\mathrm{Md}}{ }_{\mathrm{jkt}} / \mathrm{G}^{\mathrm{Td}}{ }_{\mathrm{jkt}}\right)$ in computing our estimates and assuming that the GTAP data is equally inflated for both domestic $\left(\mathrm{G}^{\mathrm{Td}-\mathrm{Md}}{ }_{\mathrm{jkt}}\right)$ and imported government demand $\left(\mathrm{G}^{\mathrm{Md}}{ }_{\mathrm{jkt}}\right)$, the former shares are likely to remain unaffected.

Finally, data on government demand in GTAP only includes consumption, which is likely to underestimate foreign market access in sectors ${ }^{9}$ where the share of public investment demand in

\footnotetext{
${ }^{9}$ These could include machinery, equipment, utilities, construction, repair and installation services, architectural and engineering services, land and air transport services, and sewage-disposal and sanitation services.
} 
total public demand is significant ${ }^{10}$. This said, there is no a priori reason to expect public investment demand in these sectors to be met more by imports than domestically, which suggests that the magnitude of the bias in estimating market access in these sectors may not be very significant.

Despite these drawbacks, however, in the absence of actual data, the use of this methodology cannot be substituted.

The estimates of the EU's access in these non-GPA public markets in the year 2007 using our methodology are reported in Table 2 below. The estimates of the EU's access in these public markets are as follows: Brazil - $€ 3.9-€ 11.9 \mathrm{mn}(11.7 \%$ of total foreign procurement); China $€ 22.8$ - €68.3 mn (19.5\% of total foreign procurement); India - €23.8 - €71.4 mn (18.6\% of total foreign procurement); Russia - €6.5 - €19.5 mn (42.1\% of total foreign procurement); and Turkey - €28.2 - €84.7 mn (41.7\% of total foreign procurement). Note that Table 2 provides a range of estimates depending on whether the contestable procurement market in the non-GPA country is 10 or $30 \%$ of adjusted government expenses.

Table 2: Estimates of the EU's access in select non-GPA country procurement markets $\left(€^{`} 000 \mathrm{~s}, 2007\right)$

\begin{tabular}{|c|c|c|c|c|c|c|c|c|c|c|}
\hline Sectors & B razil $^{\text {a }}$ & Brazil $^{\text {b }}$ & China $^{\mathrm{a}}$ & China $^{b}$ & India $^{a}$ & India $^{b}$ & Russia $^{a}$ & Russia $^{\text {b }}$ & Turkey ${ }^{\mathrm{a}}$ & Turkey $^{\mathrm{b}}$ \\
\hline Agriculture forests fishery & 44.5 & 133.6 & 1.6 & 4.7 & 34.8 & 104.5 & 81.0 & 243.1 & 1451.1 & 4353.3 \\
\hline Mining and energy extraction & 0.0 & 0.0 & 0.0 & 0.0 & 0.0 & 0.0 & 0.0 & 0.0 & 0.0 & 0.0 \\
\hline Food beverages tobacco & 37.4 & 112.1 & 0.0 & 0.0 & 64.2 & 192.7 & 18.5 & 55.5 & 527.1 & 1581.2 \\
\hline Textiles & 27.6 & 82.8 & 0.0 & 0.0 & 263.8 & 791.5 & 1136.6 & 3409.8 & 876.2 & 2628.6 \\
\hline Wearing apparel & 7.1 & 21.2 & 0.0 & 0.0 & 220.6 & 661.8 & 5.6 & 16.9 & 315.6 & 946.8 \\
\hline Leather products & 7.4 & 22.1 & 0.0 & 0.0 & 0.0 & 0.0 & 11.9 & 35.8 & 140.0 & 420.1 \\
\hline Wood products & 1.3 & 4.0 & 0.0 & 0.0 & 0.0 & 0.0 & 0.0 & 0.0 & 26.3 & 78.9 \\
\hline Paper products, publishing & 164.2 & 492.6 & 0.0 & 0.0 & 2955.3 & 8865.9 & 0.0 & 0.0 & 3042.5 & 9127.4 \\
\hline Petroleum, coal products & 0.0 & 0.0 & 0.0 & 0.0 & 0.1 & 0.3 & 0.0 & 0.0 & 3.2 & 9.7 \\
\hline Chemical, rubber, plastic products & 789.1 & 2367.4 & 1.7 & 5.1 & 2027.5 & 6082.5 & 4611.5 & 13834.5 & 5078.2 & 15234.6 \\
\hline Mineral products nec & 17.7 & 53.2 & 0.0 & 0.0 & 2.6 & 7.9 & 0.0 & 0.0 & 142.3 & 426.8 \\
\hline Ferrous metals & 21.1 & 63.4 & 0.0 & 0.0 & 0.0 & 0.0 & 0.0 & 0.0 & 284.2 & 852.7 \\
\hline Metals nec & 0.0 & 0.0 & 0.0 & 0.0 & 0.0 & 0.0 & 0.0 & 0.0 & 0.0 & 0.0 \\
\hline Metal products & 30.7 & 92.2 & 0.0 & 0.0 & 163.2 & 489.6 & 5.9 & 17.7 & 234.6 & 703.8 \\
\hline Motor vehicles and parts & 659.4 & 1978.3 & 0.0 & 0.0 & 2561.4 & 7684.2 & 404.0 & 1212.1 & 7943.9 & 23831.6 \\
\hline Transport equipment nec & 2.4 & 7.2 & 0.0 & 0.0 & 313.9 & 941.7 & 97.6 & 292.8 & 0.0 & 0.0 \\
\hline Electronic equipment & 71.5 & 214.6 & 0.0 & 0.0 & 4251.9 & 12755.6 & 22.6 & 67.7 & 1872.0 & 5615.9 \\
\hline Machinery and equipment nec & 111.1 & 333.2 & 0.0 & 0.0 & 3950.4 & 11851.1 & 11.4 & 34.1 & 817.9 & 2453.8 \\
\hline Manufactures nec & 15.6 & 46.9 & 0.0 & 0.0 & 85.5 & 256.4 & 73.0 & 218.9 & 708.1 & 2124.3 \\
\hline Electricity & 0.0 & 0.0 & 0.0 & 0.0 & 0.0 & 0.0 & 0.0 & 0.0 & 0.0 & 0.0 \\
\hline Gas manufacture, distribution & 0.0 & 0.0 & 0.0 & 0.0 & 18.3 & 55.0 & 0.0 & 0.0 & 7.9 & 23.7 \\
\hline Transport Svs & 805.0 & 2414.9 & 2997.1 & 8991.4 & 747.8 & 2243.5 & 11.0 & 32.9 & 779.0 & 2336.9 \\
\hline Other commercial svs & 421.9 & 1265.6 & 4704.3 & 14112.8 & 3270.9 & 9812.8 & n.a. & n.a. & 2980.4 & 8941.1 \\
\hline Other govt. svs & 746.2 & 2238.7 & 15071.6 & 45214.7 & 2863.5 & 8590.6 & n.a. & n.a. & 985.2 & 2955.5 \\
\hline Total & 3981.4 & 11944.1 & 22776.2 & 68328.6 & 23795.9 & 71387.6 & 6490.0 & 19470.0 & 28215.6 & 84646.9 \\
\hline Total contestable market ( $€$ bn) & 9.3 & 27.9 & 17.2 & 51.6 & 6.1 & 18.3 & 8.7 & 26.1 & 3.8 & 11.4 \\
\hline Total FP $(€ \mathrm{mn})$ & 34.1 & 102.3 & 116.9 & 350.7 & 127.9 & 383.7 & 15.4 & 46.2 & 67.6 & 202.8 \\
\hline Coverage, year & \multicolumn{2}{|c|}{ A1-3 2006} & \multicolumn{2}{|c|}{ A1-3 2004} & \multicolumn{2}{|c|}{ A1-3 2007} & \multicolumn{2}{|c|}{ A1-3 2007} & \multicolumn{2}{|c|}{ A1-3 2007} \\
\hline \multicolumn{11}{|l|}{ Share of EU's market access in: } \\
\hline Total contestable market $(\%)$ & \multicolumn{2}{|c|}{0.04} & \multicolumn{2}{|c|}{0.13} & \multicolumn{2}{|c|}{0.39} & \multicolumn{2}{|c|}{0.07} & \multicolumn{2}{|c|}{0.74} \\
\hline Total FP (\%) & \multicolumn{2}{|c|}{11.7} & \multicolumn{2}{|c|}{19.5} & \multicolumn{2}{|c|}{18.6} & \multicolumn{2}{|c|}{42.1} & \multicolumn{2}{|c|}{41.7} \\
\hline
\end{tabular}

Source:UNSNA, OECD, GTAP, UN Comtrade, OECD Bilateral Trade in Services; own calculations

Note:(1) There is a range of estimates depending on whether the contestable procurement market is (a) 10 or (b) $30 \%$ of adjusted government expenses. (2) FP stands for foreign procurement.

\footnotetext{
${ }^{10}$ If we compare total public spending in 2007 from GTAP data (which come from Eurostat input-output tables) to Eurostat data on government spending, then from total public expenditure of $€ 7 \mathrm{bn}$, about $€ 320 \mathrm{mn}$ is public capital investment, which gives us a share of $4.5 \%$. Assuming that half of this is defence-related expenditure, $2.25 \%$ of the total "non-defense" government budget could be in the investment account. Thus we could increase the size of public demand in "investment-heavy" sectors by $2.25 \%$ to account for the "missing" public investment demand component. I would like to thank Joe Francois for this information.
} 
As a share of total foreign procurement by these governments, the EU's market access is significant in Russia and Turkey, while as a share of a partner's total contestable market, India's public markets are also important to the EU, which helps explain the importance that the EU has attached to this subject in its bilateral trade negotiations with India.

In terms of sectoralcomposition, the following sectors are important from the perspective of the EU's access in each of these public markets (these sectors accounted for at least $10 \%$ of the EU's total access in each market):

Brazil: Chemicals \& rubber, motor vehicles \& parts, transport, OCS (other commercial services) \& OSG (other government services) together accounted for $85.9 \%$ of the EU's access in Brazil's public market.

India: Paper, motor vehicles, electronic equipment, other machinery \& equipment, OCS \& OSG together accounted for $83.4 \%$ of the EU's access in India's public market.

Russia: Textiles, chemicals \& rubber; together accounted for $88.6 \%$ of the EU's access in Russia's public market.

Turkey: Paper, chemicals, rubber, motor vehicles \& OCS together accounted for $67.5 \%$ of the EU's access in Turkey's public market.

European firms are thus likely to gain more in these sectors from any successful procurement liberalization in these partner public markets. Conversely, European interests are also more likely to be adversely affected in these sectors as a result of any protectionist measures in these partner public markets.

\section{Conclusion}

The WTO (2011a) has noted recently that the benefits of statistical reporting range from increasing transparency to encouraging non-GPA countries to accede to this plurilateral agreement. Towards the same objectives and in the absence of reliable data on the public purchases of non-GPA countries, this paper suggests a methodology to estimate both the size of procurement markets in non-GPA countries and the extent of foreign procurement therein. It also uses this methodology to provide estimates of the EU's access in the public markets of fivemajor emerging economies - Brazil, India, Russia, China and Turkey.

Several recent and on-going developments underline the significance of providing estimates of total and contestable public procurement in non-GPA countries, especially in emerging economies. Firstly, new market access opportunities ${ }^{11}$ are likely to make themselves available as a result of successful WTO negotiations on a revised GPA deal, which may also get non-GPA countries interested. Secondly, long-standing opponents of the GPA are already beginning to get interested. India, for instance, acquired an Observer status in February 2010 and the WTO (2011b), in its revised text, exhorts more and more non-signatories to do the same to enable them to learn more about the system in place. Thirdly, an increasing number of non-GPA countries are making commitments on this subject in their PTAs (for details see Anderson et.al. 2011b).

Finally, in a significant departure from Article XIX: 5(b) of the URGPA, the number and value of central government contracts are no longer required to be reported by the nationality of the winning supplier in Article XVI: 4 of the revised GPA text. This would make it impossible to get information on actual foreign market access in the central government procurement markets of the GPA countries. The methodology suggested in this paper can therefore also be used to provide estimates of de facto market access in GPA countries.

\section{References}

Anderson, R. D., P. Pelletier, K. Osei-Lah\& A. C. Müller (2011a). 'Assessing the value of future accessions to the WTO Agreement on Government Procurement (GPA): Some new data sources,

\footnotetext{
${ }^{11}$ According to WTO estimates, the revised GPA deal is expected to bring extra procurement opportunities worth $€ 100$ bn (EC Press Release IP/11/1556).
} 
provisional estimates, and an evaluative framework for individual WTO Members considering accession,' WTO Staff Working Paper ERSD-2011-15.

Anderson, R. D., A. C. Müller, K. Osei-Lah, J.P.de Leon \& P. Pelletier (2011b). 'Government procurement provisions in regional trade agreements: A stepping stone to GPA accession?' in Arrowsmith\& Andersoned.The WTO Regime on Government Procurement: Challenge \& Reform, Cambridge University Press, Chapter 20, pp 561-656.

Hoekman, B. (1997). 'Operation of the Agreement on Government Procurement, 1983-92,' in Bernard Hoekman\&PetrosMavroidis ed. Law and Policy in Public Purchasing: The WTO Agreement on Government Procurement, University of Michigan Press.

Evenett, S.J. \& A. Shingal (2006). 'Monitoring Implementation: Japan and the WTO Agreement on Government Procurement,' in Economic Development \& Multilateral Trade Cooperation, The World Bank\& Oxford University Press.

OECD (2002). 'The Size of Government Procurement Markets,' available at www.oecd.org/dataoecd/34/14/1845927.pdf.

Shingal, A. (2005). 'Services procurement under the GPA,' mimeo, ESRC Workshop on Trade in Services, University of Sussex, December.

Shingal, A. (2011). 'Services procurement under the WTO's Agreement on Government Procurement: Whither market access? World Trade Review, 10:4, 1-23.

WTO (2011a). 'Annex 6: Proposed Decision of the Committee on Government Procurement on a Work Programme on the Collection and Reporting of Statistical Data,' GPA/112, 16 December, p. 43.

WTO (2011b). 'Decisions on the Outcomes of the Negotiations under Article XXIV:7 of the Agreement on Government Procurement,' GPA/112, 16 December, p. 2. 
